\title{
FORESTRY EXPANSION DURING THE LAST DECADES IN THE PARAIBA DO SUL BASIN - BRAZIL
}

\author{
F.Carriello ${ }^{\text {a }}$, F.S. Rezende ${ }^{\text {a }}$, O.M.S.Neves ${ }^{\text {a }}$, D.A.Rodriguez ${ }^{b}$ \\ ${ }^{\text {a }}$ Federal Fluminense University, UFF- Geosciences Institute - Av. Gal. Milton Tavares de Souza, s/n - Praia Vermelha Campus, Boa \\ Viagem - Niterói - felix-carriello@vm.uff.br, fernandarezende@id.uff.br; ottomarques@id.uff.br \\ National Institute For Space Research - Earth System Science Centre - INPE/CCST Rod. Pres. Dutra, km 40, Cachoeira Paulista - SP - \\ daniel.andres@inpe.br
}

Commission VIII, WG VIII/8

KEY WORDS: forestry, remote sensing, Rain Forest, multitemporal assessment

\begin{abstract}
:
In this work, we analyze the expansion of forestry activities with Eucalyptus in the Paraiba do Sul basin, region located in Sao Paulo, Brazil, from 1986 to 2010. In this region is situated the most important and largest extension of reminiscent of Mata Atlântica Biome reminiscent. This biome has been one the most exploited Brazilian biome since 1500, when Brazilian colonization begun. To achieve this goal, we use the GIS "SPRING" and images from Landsat 5 Satellite, TM sensor from 1986, 1990, 1995, 2000, 2005 and 2010, distributed by the Brazilian National Institute for Space Research - INPE. The non-supervised-classification was applied to images in order to produce land use and land cover maps. After that, we intersect each classification for each date with the precedent date, so we can analyze the paths of each land use change, focusing forestry expansion in native's Mata Atlântica areas. The results show that eucalyptus plantations in the region have expanded mostly over fragments of Mata Atlântica. About 99.389 hectares of Mata Atlântica were transformed into forestry in 25 years, an average rate of 4000 ha per year. Clear-cut was largest between 1990 and 1995, when 22810 hectares of rain forest were cut, and between 1995 and 2000, when 21430 hectares were cut.
\end{abstract}

\section{INTRODUCTION}

The aim of this research is to study spatial and temporal assessment of the forestry expansion in the Paraíba do Sul basin, one of the largest agro-producing regions in Brazil. The region was mapped using orbital images. The Mata Atlântica is the natural biome of this region. It is one the most threatened biome in the world (Cruz e Vicens, 2007: Galindo-Leal e Camara, 2005), since 1500 when Portuguese arrived to Brasil. The first register damage was the extraction of Pau-Brasil, a tree which wood serves as dye to fabric industries in Europe and hardwood to furniture. After that, in 1800' the region was covered with coffee plantations to the external market and nowadays, since 1960, the rapid growth of eucalyptus $s p$ to produce cellulosic fiber. Environmental Zoning and strict laws to protect the biome must be implemented to assure the future of Mata Atlántica...

\section{STUDY AREA}

The Vale do Paraíba Paulista, into the Paraiba do Sul basin, is defined by SEADE (State Foundation for Data Analyzes) as a socioeconomic region (Figure 1), for administrative purposes.. Located between two major Brazilian cities: Rio de Janeiro and São Paulo and polarized by the city of São José dos Campos, the Vale do Paraíba Paulista has about 2 million people according to the
Brazilian Institute of Geography and Statistics (IBGE, 2010 ). Its economy is highly diversified, with a significant industrial sector with facilities in the areas: automotive, food and high-tech industries. Agriculture sector is represented mainly by rice cultivation and silviculture, followed by milk production. The service sector has its highest expression in religious tourism and a large number of universities. The Presidente Dutra highway, which connect the two major Brazilian cities, is the main connection route between the cities of the region.

The occupation of the region dates from the sixteenth century when the first Europeans were arrived. One of their economics activities in the region was the exploitation of the Pau-Brasil tree, which was cut and brings to Europe, where it served as dye for fabric factories. However, occupation in the region was only intensified with the coffee plantations in the beginning of the nineteenth century. This period was one of greatest economic prosperity for the region. According to Ricci (2006), coffee plantation was certainly the progress factor for the region that grew and diversified the activities of its urban centers. During the last century, forestry found ideal conditions, mainly climate and large land areas, for its development in Paraíba do Sul basin. The larger extension of this monoculture are nowadays concentrated in the study area and become one of the biggest in the country since the 1980 decade. 


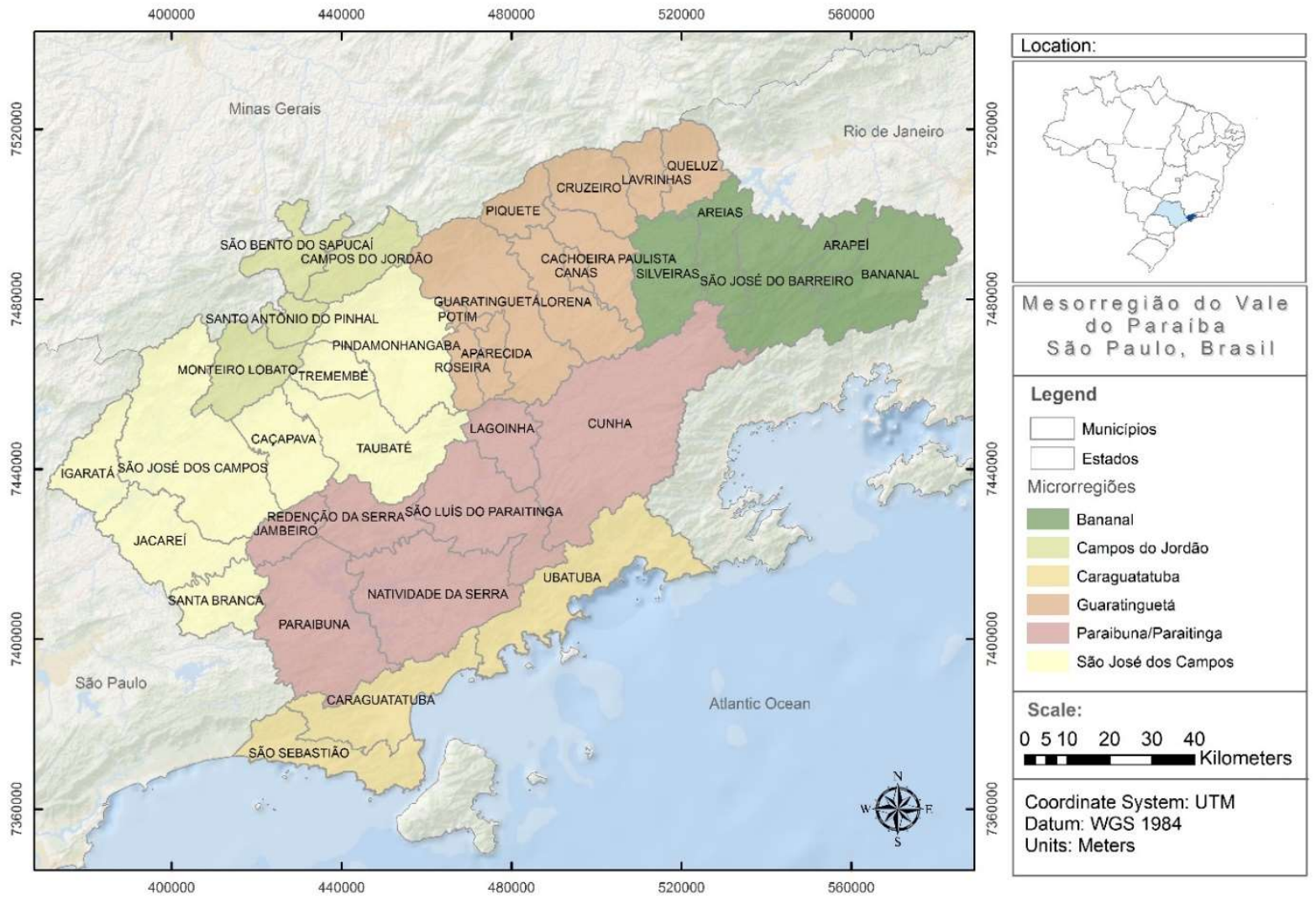

Figure 1: Study area.

\section{DATA AND METHODS}

This research carried out the chronological analysis of forestry expansion in the study area between the years 1986 and 2010. Imagery operations were performed with SPRING - System Georeferenced Information Processing (Camara et al., 1996), developed by the National Institute for Space Research - INPE. The work aimed to carry out Land use and Land Cover classification for 1986, 1990, 1995, 2000, 2005 and 2010. Therefore, two images Landsat / TM 5, whose orbit / point are: 218/76 and 219/76 were georeferenced, classified and mosaicked to each year.

A non-supervised methodology was applied to carry out the classification in all images (Jensen, 2009). After that, during the post processing classified images were remapped. Each class generated by classification was associated with a thematic class created for the study. These ratings were issued in matrix and mosaicked (two orbit-point) with the final product "Land Use Maps" for the respective years studied. These maps were analyzed in order to calculate the spatial and temporal variations of the eucalyptus culture (silviculture).. We use eight thematic classes in this work: Natural Vegetation (which represent the Mata Atlântica biome), Pasture, Silviculture, Water Bodies, Agriculture, Soil, NonClassified and Urban Area. Once Urban Area are not supposed to convert to another class, it does not appear in the table conversion (Table 1).

The classification for year 2010 was validated using more than 600 points acquired with GPS in fieldwork. Through analysis of the confusion matrix, we observed an overall accuracy of $84.5 \%$ rating and a kappa index of $80.9 \%$. Visual interpretation was also applied to each classification to correct misclassifications. After validation, each class from one year was intersected with the next date (ex. 2000 intersected with 2005) using the polygons, which allows to specify the "path" that one "polygon class" take in the next period.

\section{RESULTS}

The results of maps intersections are presented in Table 1. The values in the table represent the percentage of each Land Use Class that was changed to Silviculture from one year to another. That is, this table shows the vegetation classes, agriculture and pasture, for example, modified into forestry. 
The International Archives of the Photogrammetry, Remote Sensing and Spatial Information Sciences, Volume XLI-B8, 2016 XXIII ISPRS Congress, 12-19 July 2016, Prague, Czech Republic

\begin{tabular}{|c|c|c|c|c|c|c|c|c|}
\hline \multicolumn{2}{|c|}{ Land Uses Classes } & \multicolumn{5}{|c|}{ Transformation to } & \multirow[b]{2}{*}{ Total } & \multirow[b]{2}{*}{$\%$} \\
\hline From & To & $\begin{array}{l}1986 \\
1990\end{array}$ & $\begin{array}{l}1990 \\
1995\end{array}$ & $\begin{array}{l}1995 \\
2000\end{array}$ & $\begin{array}{l}2000 \\
2005\end{array}$ & $\begin{array}{l}2005 \\
2010\end{array}$ & & \\
\hline Agriculture & \multirow{7}{*}{ Silviculture } & 1265,00 & 16,00 & 218,00 & 274,00 & 177,00 & 1143,20 & 0.66 \\
\hline Water & & 269,8 & 44,40 & 113,30 & 190,00 & 323,40 & 616,84 & 0.36 \\
\hline $\begin{array}{l}\text { Not classified } \\
\text { (clouds) }\end{array}$ & & 5,5 & 667,90 & 2693,80 & 127,7 & 48,55 & 2571,50 & 1.49 \\
\hline pasture & & 10738,00 & 8770,00 & 9007,00 & 26532,00 & 19544,00 & 68759,00 & 39.78 \\
\hline soil & & 467,70 & 17,60 & 0 & 0 & 0 & 287,59 & 0.17 \\
\hline Burnt areas & & 0,00 & 2,21 & 69,00 & 0 & 0,16 & 71,37 & 0.04 \\
\hline vegetation & & 17414,00 & $22,810.00$ & 21430.00 & 21262.00 & 16473.00 & 99389,00 & 57.50 \\
\hline \multicolumn{2}{|c|}{ Total } & 30160,00 & $32,335.11$ & 33532.10 & 48385.70 & 36566.11 & 173126,09 & 100,00 \\
\hline
\end{tabular}

Table 1: Class conversions to silviculture trough dates.

Throughout the period analyzed, significant areas of pasture and Natural Vegetation (Mata Atlântica) were conversed to eucalyptus cultivation. It is clear that more than half of the areas converted to forestry comes from the class "Natural Vegetation". Also, this conversion accounts for $56.81 \%$ of the transformed space, which shows that the Mata Atlântica has been converted into silviculture abruptly, even though as threatened biome worldwide by human actions (Carriello e Vicens, 20011).

The trend of conversion from Natural Vegetation and Pasture into Silviculture was higher between 1990 and 1995, when 22810.00 ha of Natural Vegetation were converted to Silviculture. Also between 1995 and 2000 this trend show a large value, when 21430.00 ha of Natural Vegetation were converted to forestry. It is in this period (2000-2005) that the greatest total conversed area lies, comprising 48385,70 ha of territory. For the early years - 1986 and 1990 - the change to forestry affected 30160,00 ha of territory. This fact underlines the intensification of deforestation and conversion of use, and consequent fragmentation of the Mata Atlântica, presents in the study area. Pasture and Natural Vegetation were the two classes that contribute most to conversion. During this period,
$39,78 \%$ of Pasture and $57.50 \%$ of Natural Vegetation were converted to Silviculture. Although the large rates of conversion along the period, there is a negative trend in the Natural VegetationSilviculture conversion from 1990 to 2010 . On the other hand, the Pasture-Silviculture conversion presents a positive trend since 1995 until 2005. The demands of paper and cellulose industry enhances silviculture and generates significant impacts to the region, such as the fragmentation of remaining Mata Atlántica areas and the possible groundwater lowering, in addition to soil depletion in large areas (Neves et al., 2013a).

Figure 2 shows the expansion of silviculture in the region, where is noted the expansion of silviculture in little patches throughout the region since 2000 . This could be explained by the pulverization of silviculture, which is carried out in a large number of small farms. Small farms of forestry grew 7 (seven) times between 1995 to 2006 (IBGE, 2010). This dynamic in silviculture growth increases fragmentation in Mata Atlântica.

Neves et al, (2013b) in a previous research, point out that when Brazil's economy grows, silviculture also grows in a positive correlation and temporary crops are decreasing in the region. 


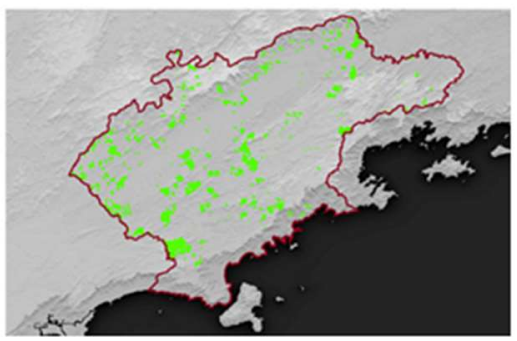

Forestry 86

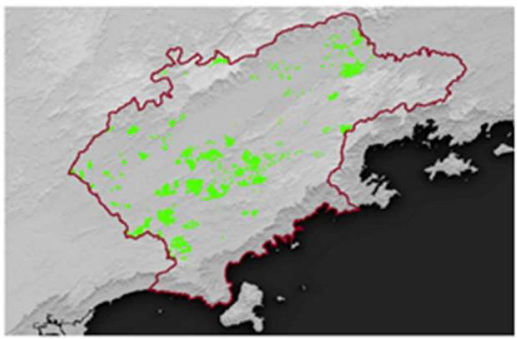

Forestry 95

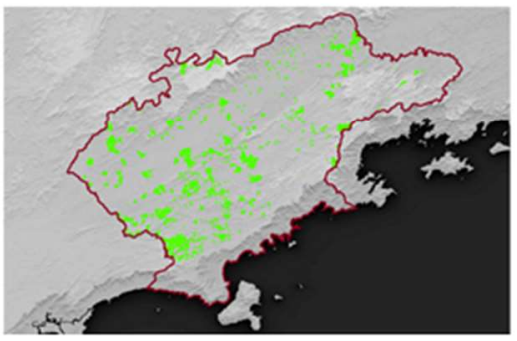

Forestry 2005

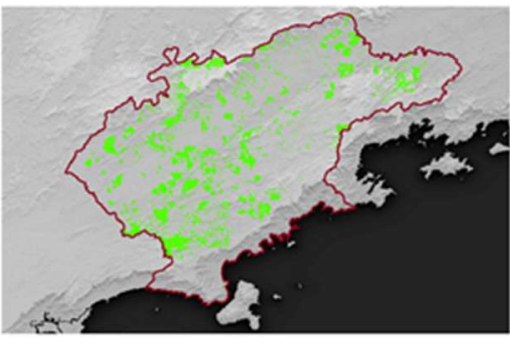

Forestry 90

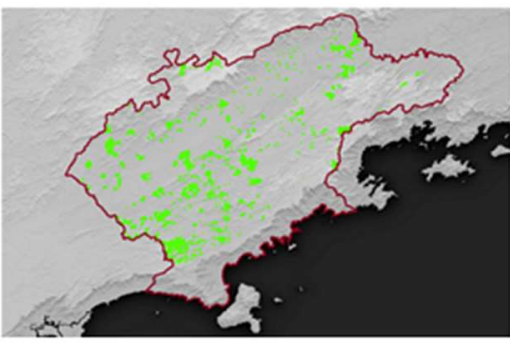

Forestry 2000

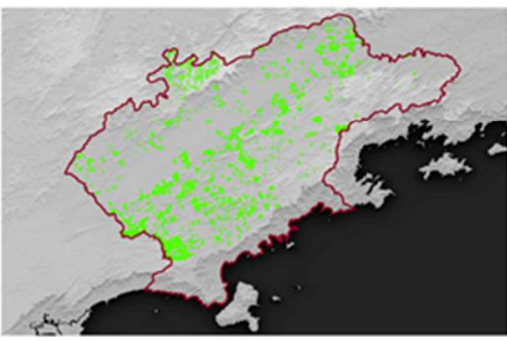

Forestry 2010

Figure 2: Expansion of Silviculture in Paraiba do Sul basin expansion along the period studied

\section{CONCLUSIONS}

We presented in this paper a trend in Land Cover Change that occurs in Paraiba do Sul basin. Great areas of Mata Atlântica, the natural biome of the region, are being converted into silviculture. Silviculture has different characteristics from the natural forest, such as structure, dynamic, hydrology and mainly biodiversity. Like many others monocultures, for example coffee plantation in
XIX century, silviculture vanishes a great part of Mata Atlântica. Results alerts about the necessity of implementation of public policies, such as Environmental Zoning, and reinforce the importance of focalization by governments to protect the reminiscent of Mata Atlântica. 


\section{ACKNOWLEDGEMENTS}

We would like to thanks to $\mathrm{CNPq}$ - National Counsel of Technological and Scientific Development - the scholarship to the second author.

\section{REFERENCES}

Camara, G., Souza, R.C.M., Freitas, U.M., Garrido, J.,2006. "SPRING: Integrating remote sensing and GIS by object-oriented data modelling" Computers \& Graphics, 20: (3) 395-403, MayJun 1996.

Carriello, F. e Vicens, R.S.,2011. Silvicultura de eucalipto no vale do Paraíba do Sul/SP no período entre 1986 e 2010. In: Simpósio Brasileiro de Sensoriamento Remoto - SBSR, XV. 2011. Curitiba, PR, Brasil. Anais...Curitiba:2011. p. 6403

Cruz, C. B. M.; Vicens, R. S., 2007. Levantamento da cobertura vegetal nativa do bioma Mata Atlântica. Relatório final. Rio de Janeiro, 2007, p. 84. (in Portuguese)

http://sistemas.mma.gov.br/sigepro/arquivos/ 6/relatorio final M Atla 4.pdf. (22 oct.. 2015)

FIBGE - Fundação Instituto Brasileiro de Geografia e Estatística. Censo 2010. (in portuguese). http://www.censo2010.ibge.gov.br (30 nov 2015)

Galindo-Leal, C., Câmara, I. G., 2005. Mata Atlântica: uma síntese. In: Galindo-Leal, C., Câmara, I. G. (Eds.). Mata

Atlântica: biodiversidade, ameaças e perspectivas. São Paulo,
Fundação SOS Mata Atlântica/Belo Horizonte, Conservação Internacional do Brasil, p.3-11.

Jensen, J. R. , 2009. Sensoriamento remoto do ambiente: uma perspectiva em recursos terrestres. Rio de Janeiro, Editora Parêntese, 2009. Cap. 1-5, p.672.

Hueck, K., 1972. As florestas da América do Sul. São Paulo: Editora da Universidade de Brasília, Editora Polígono, 1972. $466 \mathrm{p}$.

Neves, O.M.S.; Carriello, F.; Rodriguez, D.A., 2013a. A expansão da cultura de eucalipto na região do Vale do Paraíba entre 1995 e 2010 e sua relação com as características hidrológicas da bacia. In: Simpósio Brasileiro e Sensoriamento Remoto (SBSR), 16., 2013, Foz do Iguaçu, Anais...INPE, 2013. Artigos, p. 7608-7615.

Neves, O.M.S.; Carriello, F.; Rodriguez, D.A., 2013b. A expansão da cultura de eucalipto na Região do Vale do Paraíba e sua relação com as características hidrológicas da bacia.(in portuguese) http://mtc-m16d.sid.inpe.br/col/sid.inpe.br/mtcm19/2012/09.27.11.54/doc/Otto\%20Marques\%20do s\%20Santos\%20Neves.pdf (12 dec. 2015)

Ricci, F., 2006. A economia cafeeira e as bases do desenvolvimento no Vale do Paraíba paulista. Revista de História Econômica \& Economia Regional Aplicada - Vol. $1 \mathrm{~N}^{\mathrm{o}} 1$ Jul-Dez 2006 